\title{
Effect of Soil Salinity at Germination and Early Growth Stages of Two Maize (Zea mays L.) Cultivars in Saudi Arabia
}

\author{
Mohammed Awad, Samir G. Al Solaimani and Fathy S. El-Nakhlawy \\ Department of Arid Land Agriculture, Faculty of Meteorology Environment and Arid Land \\ Agriculture, King Abdulaziz University, Saudi Arabia \\ Corresponding author: mohammed_aay@yahoo.com
}

\begin{abstract}
Laboratory experiments were conducted to investigate the effect of different salinity levels of soil extractions on maize during the germination and early growth stages. The study was carried out at the Department of Arid Land Agriculture, King Abdulaziz University, Kingdom of Saudi Arabia during the year 2014. The maize cultivars used in the study were Single Hybrid 13 Bashair (white grain) and Tri Hybrid 352 (yellow grain) cvs. The salinity levels of soil extraction were 3.72, 6.23, 10.02 and 14.02, $\mathrm{mS} / \mathrm{cm}$, while distilled water was used as a control. Analysis of variance (ANOVA) showed that there were significant differences $(P<0.05)$ among salinity levels, maize cultivars and interaction effects for all investigated traits. Salt concentration had a significant effect on all measured traits. The mean values for germination (\%), salinity tolerance index and seed vigor index of the white and yellow cultivars were 74 and $76 \%, 66.765$ and 70.492, and 4204.0 and 4169.5 respectively. There was no significant difference at $(p<0.05)$ in all measured traits between the two cultivars except on root length, in which white grain cultivar was $5.63 \mathrm{~cm}$, while the yellow grain cultivar was $4.94 \mathrm{~cm}$.
\end{abstract}

Keywords: Maize, salinity, germination, arid land

\section{Introduction}

Salinity is becoming the major limiting factor for high agricultural production in soil of arid and semiarid regions. Concentration of high salts in the soil has negative impact on the germination and development of the crops (Rahman et al. 2000). Delay of germination and seedling growth due to high salts concentration was observed by many researchers (Pandeyand Thakrar, 1997). However, fields crops and all plants are differ in their tolerance to salt stress (Torechand Thompson, 1993). Maize as dominant food crop grow in many arid regions has been classified as a moderately sensitive crop to salinity (Ouda et al. 2008). Salinity affects the crop adversely during germination and early growth stages (Carpici et al. 2009). Germination and optimal seedling growth are very important for better crop establishment. Decrease of germination rates and seedlings growth under high salinity condition was reported by Jamil et al. 2006 and Asaadi, 2009. 
Soil of arid region of western Saudi Arabia is highly varied in salinity concentration. This variation could be attributed to cultural practices such as quality of irrigation water and excessive use of chemical fertilizers. Therefore, this study was mainly conducted to evaluate the effect of different saline soil extracts on seed germination and seedling growth of two maize cultivars and make a comparison toward salinity stress to select the most tolerant one which can be grown on saline soil.

\section{Materials and Methods}

\section{Soil extract and salinity measurement}

Saturated paste method was chosen in order to provide more representative and accurate measurement of total soluble salts in the soil solution. Dried and sieved soil samples collected from maize farm were mixed with de-ionized water in glass beakers to prepare saturated soil paste. After mixing, the samples were allowed to stand for one to two hours and then saturation criteria were rechecked. The extract of saturated paste was collected by filtration. Electrical conductivity meter was calibrated by standard solution of potassium chloride $(\mathrm{KCl})$, whereas, a concentration of $0.01 \mathrm{~N} \mathrm{KCl}$ gives EC reading of $1.4118 \mathrm{mmohs} / \mathrm{cm}$ at $25^{\circ} \mathrm{C}$. Soil extracts of all samples were labeled and kept to irrigate incubated maize grain when needed.

\section{Experimental materials and procedure}

This study was carried out at the King Abdulaziz University, Faculty of Meteorology, Environment and Arid Land Agriculture, Department of Arid Land Agriculture in Saudi Arabia in the year 2014. Grains of two maize (Zea maize L) cultivars were obtained from Egypt. The specific maize cultivars used in the research were Single Hybrid 13 Bashair (white grain) and Tri Hybrid 352 (yellow grain), designated as CV1 and CV2 respectively. The salinity concentrations of the different soil extracts used were $3.72,6.23,10.02$ and $14.02, \mathrm{mS} / \mathrm{cm}$. These salinity levels were obtained by extracting soil solutions from different soil samples of diversified salinity concentrations. Distilled water $(0 \mathrm{mS} / \mathrm{cm})$ was used as a control. Germination experiment was conducted in a laboratory at room temperature following the procedure described by Mamo et al. 1996. Petri dishes with a diameter of $10 \mathrm{~cm}$ lined with filter paper as absorbent material were supplied with $10 \mathrm{ml}$ of each treatment solution and the control. Following this, twenty uniform seeds of each maize cultivar were placed in each petri dish and the petri dishes were arranged in a Randomized Complete Block Design (RCBD) with three replications. Soil solution extract was added when needed to keep the absorbent material moist. The germinated seeds were counted when the radical length was more than $3 \mathrm{~mm}$. The number of germinated seeds was recorded daily, the final germination percentage (FGP)calculated as follows:

$$
\text { Germination }(\%)=\left(\frac{\text { Number of seeds germinated }}{\text { Number of seeds on tray }}\right) * 100
$$




\section{Results and Discussion}

The effect of different salinity levels $(3.72,6.23,10.02$ and $14.02, \mathrm{mS} / \mathrm{cm})$ on two maize cultivars [Single Hybrid 13 Bashair (white grain) and Tri Hybrid 352 (yellow grain)] germination capacity, fresh and dry weight; length of shoot and root including their Salt Tolerance Index (STI) and Seed Vigorous Indices (SVI) at germination and early growth stages were investigated, analyzed, compared, graphically presented and discussed below.

Table 1.Comparison between the two cultivars of maize against salt levels for all measured traits

\begin{tabular}{|l|c|c|c|c|c|c|c|c|c|}
\hline Traits & $\begin{array}{c}\text { Germin- } \\
\text { ation } \\
(\%)\end{array}$ & $\begin{array}{c}\text { Shoot } \\
\text { fresh } \\
\text { weight/p/ } \\
\mathrm{mg}\end{array}$ & $\begin{array}{c}\text { Shoot dry } \\
\text { weight/p/ } \\
\mathrm{mg}\end{array}$ & $\begin{array}{c}\text { Shoot } \\
\text { length/ } \\
\mathrm{cm}\end{array}$ & $\begin{array}{c}\text { Root } \\
\text { fresh } \\
\text { weight/p/ } \\
\mathrm{mg}\end{array}$ & $\begin{array}{c}\text { Root dry } \\
\text { weight/p/ } \\
\mathrm{mg}\end{array}$ & $\begin{array}{c}\text { Root } \\
\text { length/ } \\
\mathrm{cm}\end{array}$ & $\begin{array}{c}\text { S.T.I } \\
(\%)\end{array}$ & S.V.I \\
\hline $\begin{array}{l}\text { Whites. } \\
\text { grain }\end{array}$ & $74.000 \mathrm{a}$ & $110.395 \mathrm{a}$ & $17.9627 \mathrm{a}$ & $5.1687 \mathrm{a}$ & $53.034 \mathrm{a}$ & $9.0773 \mathrm{a}$ & $5.6293 \mathrm{a}$ & $66.765 \mathrm{a}$ & $4204.0 \mathrm{a}$ \\
\hline $\begin{array}{l}\text { Yellow } \\
\text { grain }\end{array}$ & $76.000 \mathrm{a}$ & $112.916 \mathrm{a}$ & $18.2480 \mathrm{a}$ & $4.9487 \mathrm{a}$ & $51.423 \mathrm{a}$ & $9.0827 \mathrm{a}$ & $4.9640 \mathrm{~b}$ & $70.492 \mathrm{a}$ & $4169.5 \mathrm{a}$ \\
\hline $\begin{array}{l}\text { L.S.D } \\
\text { (0.05) }\end{array}$ & 14.905 & 7.1944 & 1.677 & 0.9097 & 8.3171 & 0.9018 & 0.3324 & 5.663 & 1183 \\
\hline
\end{tabular}

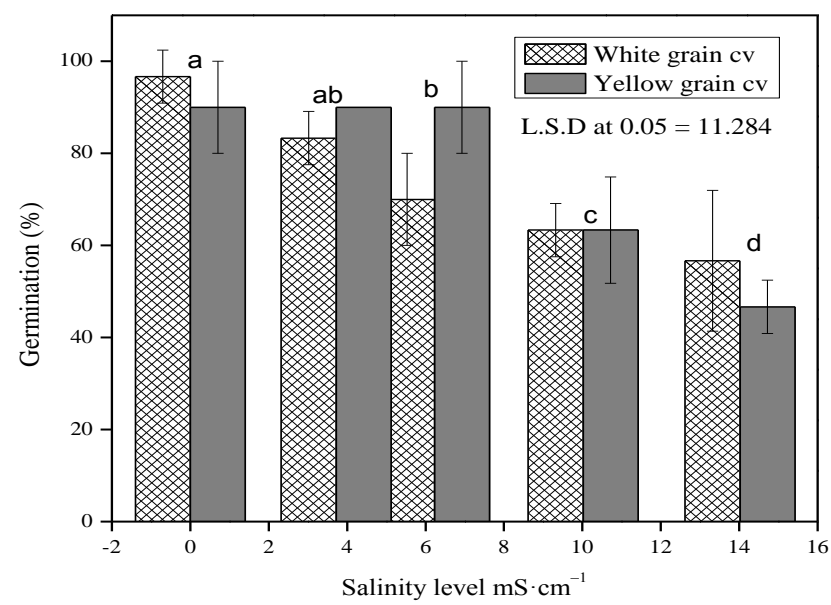

Figure 1. Germination response of maize cultivars against salinity levels

The results showed that all measured traits of tested maize cultivars were significantly affected by salinity stress at germination and early growth stages. White grain cultivar performed better at the first three levels of salinity stress $(0,3.72$ and $6.23 \mathrm{mS} / \mathrm{cm})$ while the germination decreased severely at salinity levels 10.02 and $14.02 \mathrm{mS} / \mathrm{cm}$. yellow grain cv showed gradual decrease in germination with salinity level increase (Figure 1). The highest germination percentage at $0.0 \mathrm{mS} / \mathrm{cm}$ for both cultivars was ascribed to lack of salts in the medium culture. 


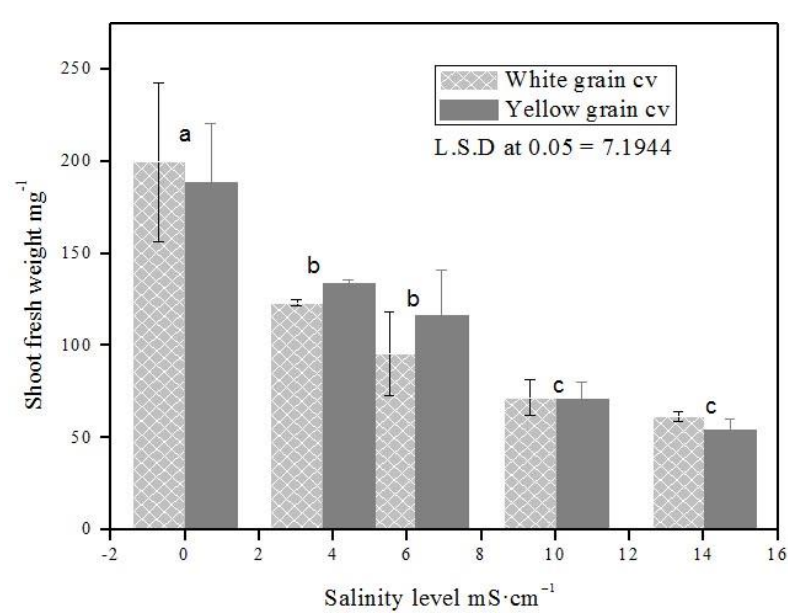

Figure 2. Shoot fresh weight vs. Salinity levels

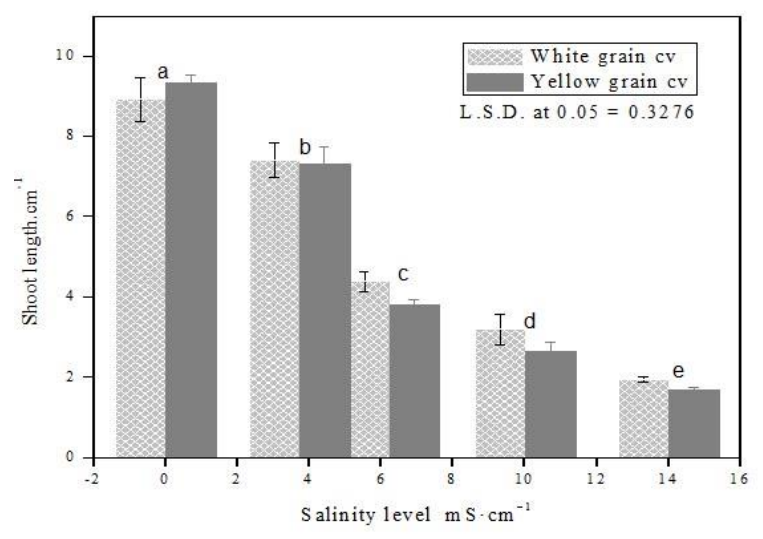

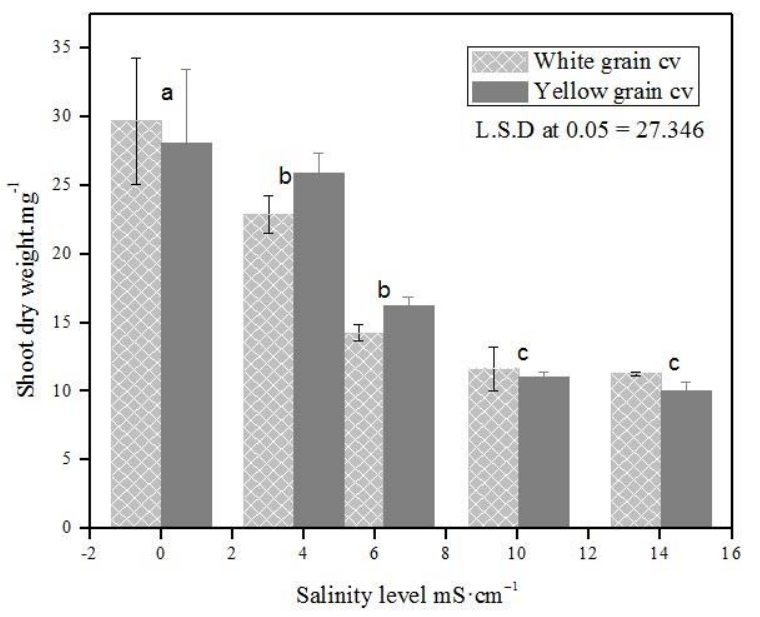

Figure 3. Shoot dry weight vs. Salinity levels

Figure 4.Shoot length vs. salinity levels

Shoot fresh weights, dry weights and shoot length were adversely affected by salinity increase (Figure $2,3,4)$. The average fresh weight of the control for white grain was $192 \mathrm{mg} / \mathrm{plant}$, this value was decreased gradually throughout the salinity increase level to reach $53 \mathrm{mg} / \mathrm{plant}$ at $14.02 \mathrm{mS} / \mathrm{cm}$. for yellow grain cv. The average weight of the control was $186 \mathrm{mg} / \mathrm{plant}$ and the lowest was $49 \mathrm{mg} / \mathrm{plant}$ at the highest salinity level (Table 1). The overall averages of the fresh weight for both cultivars at all salinity levels were $112.9 \mathrm{mg} /$ plant for yellow grain cv. and $110.4 \mathrm{mg} /$ plant for white grain cv. (Table 1). The shoot dry weights for both varieties were decreased according to salinity increase (Figure 3 ). There was a decrease in fresh and dry weight between salinity levels of 3.72 and $6.23 \mathrm{mS} / \mathrm{cm}$, and between 10.02 and $14.02 \mathrm{mS} / \mathrm{cm}$ but the differences were not significant. Results of this study is in agreement with previous work conducted by Hussein et al. (2007) who found that there was negative relationship between vegetative growth parameters and salinity level increase. The same researchers reported that shoot dry weight was $52.01 \mathrm{mg} / \mathrm{plant}$ at $0.0 \mathrm{ppm}$ and it was decreased linearly with salinity increase to $25.26 \mathrm{mg} / \mathrm{plant}$ at salinity level of $4000 \mathrm{ppm}$. Similar results were also reported by Mansour et al. 2005 in a similar study. It is evident that parameters such as fresh weight, dry weight and length of root were showed clear declining towards increase of salinity levels (Figure 5, 6, 7) which is further confirmed by traits comparison shown in Table 1. 


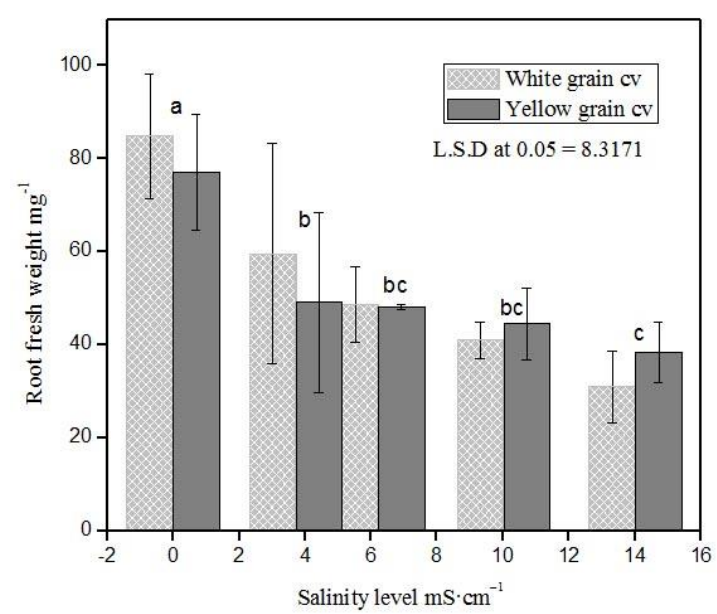

Figure 5.Root fresh weight vs. salinity levels

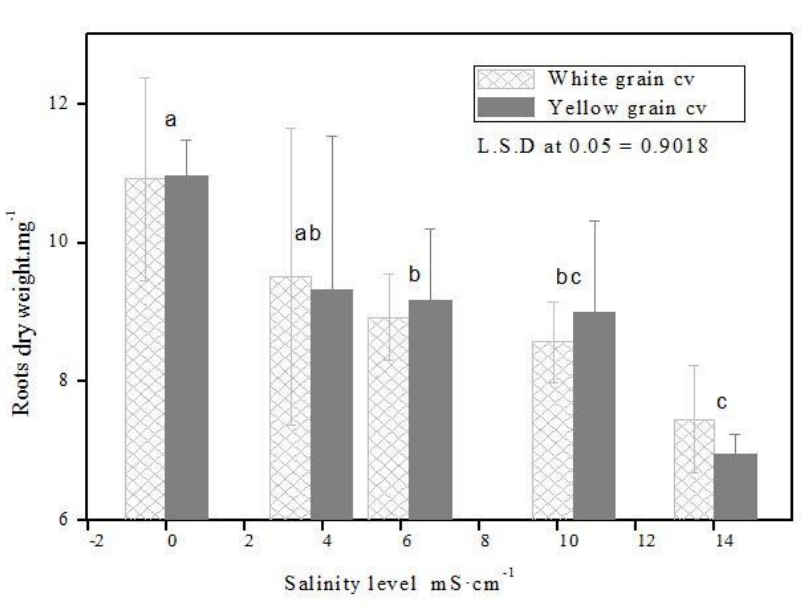

Figure 6.Root dry weight vs. salinity levels

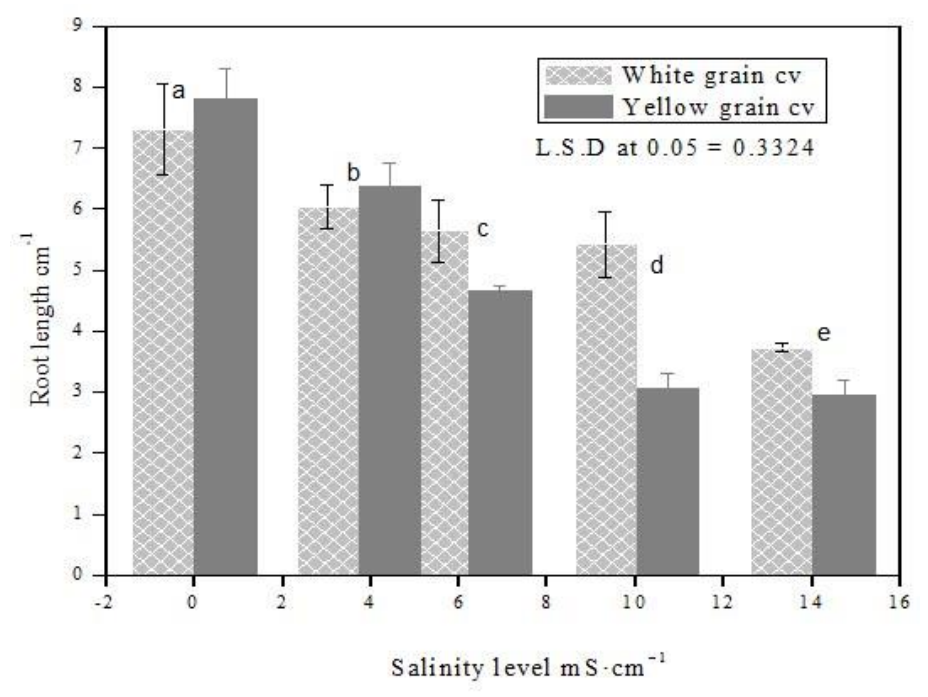

Figure 7.Root length vs. salinity levels

Salt Tolerance Index (STI) is an important parameter for the selection of the cultivar in the arid and saline soil. Yellow grain cultivar showed better salt tolerance index in a comparison with the white grain cultivar, however, the difference was not significant (Figure 8). Generally, as the salt concentrations increased the salt tolerance indices of the cultivars decreased. Therefore, the highest value of salt tolerance index was determined at the control and decreased to the highest salinity level. Data regarding Seed Vigorous Indices (SVI) of the two tested cultivars show that white grain cultivar is more vigorous than the yellow grain cultivar, although there was no significant differences (Figure 9). 


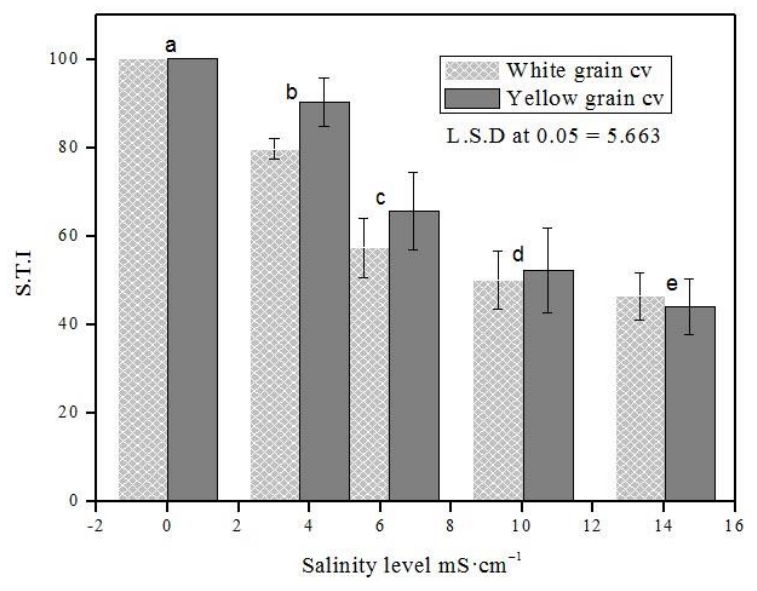

Figure8.Salt Tolerance Index vs. salinity levels

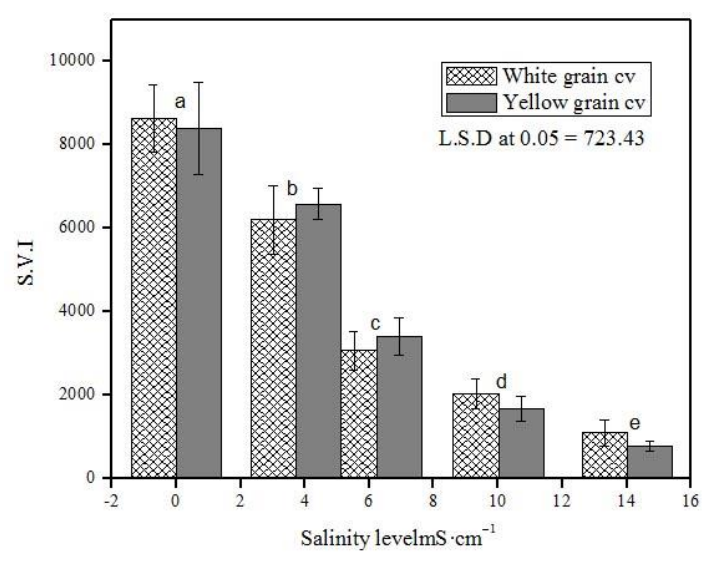

Figure 9.Seed Vigorous Indices vs. salinity levels

Some research studies have reported that there may not be positive correlation between salt stress tolerance at germination stage and during other growth stages (Mujeeb et al., 2008). Therefore, a decision on the selection of suitable and salt tolerant cultivar is difficult to be taken based on germination $\%$ or salt stress tolerance during early growth stages.

\section{Conclusion}

In this study, saline soil extract was used to understand the actual effect of soil salinity on two maize cultivars. Salt stress adversely affected germination percentage and all measured traits of the two cultivars of maize seedlings. The study proved that there were no significant differences between the two studied cultivars in most of germination parameters. Selection of salt tolerant cultivars should be based on small scale experiment on the salt affected site.

\section{Acknowledgement}

This project was financially supported by King Abdulaziz City for Science and Technology (KACST), No (22-12- ت- - - S), Saudi Arabia. 


\section{References}

Asaadi, A.M. 2009. Investigation of salinity stress on seed germination of Trigonellafoenumgraecum.Res JBiol Sci., 4, 1152-1155.

Carpici, E.B., Celik, N., \&Bayram, G. 2009. Effects of salt stress on germination of some maize (Zea mays L.) cultivars. Afr J Biotechnol, 8, 4918-4922.

Dahnke, W.C and D.A. Whitney. 1988. Measurement of Soil Salinity. pp. 32-34. In W.C. Dahnke (ed.) Recommended chemical soil testprocedures for the North Central Region. North Dakota Agric. Exp. Stn. Bull. 499. on corn cv. Sunahry, Pak. J. Biological Sci., 3(9): 1459-1463.

Hussein M.M., Balbaa L.K., Gaballah M.S. 2007. Salicylic Acid and Salinity Effects on Growth of Maize Plants. Res. J. Agric. Biological Sci. 3(4): 321-328.

Jamil, M., Lee, D.B., Jung, K.Y., Ashraf, M., Lee, S.C., \&Rha, E.S. 2006.Effect of salt (NaCl) stress on germination and early seedling growth of four vegetables species.J Cent EurAgr., 7, 273282.

Mamo, T., C. Richter and B. Heiligatag, 1996.Response of some varieties of durum wheat and tef to salt stress. Afr. CropSci. J., 4(4): 423-432

Mansour M.M.F., Salama K.H.A., Ali F.Z.M., AbouHadid A.F. (2005). Cell and Plant Repsonses to $\mathrm{NaCl}$ in Zea mays L. Cultivars Differing in Salt Tolerance. Gen. Appl. Plant Physiol. 31(1-2): 29-41.

Mujeeb-ur-Rahman, Umed Ali Soomro, Mohammad Zahoor-ul-Haq and ShereenGul, Effects of $\mathrm{NaCl}$ Salinity on Wheat (TriticumaestivumL.) Cultivars, World Journal of Agricultural Sciences 4 (3): 398-403, 2008

Ouda S.A.E., Mohamed S.G., Khalı1 F.A. 2008. Modeling the Effect of Different Stress Conditions on Maize Productivity Using Yield-Stress Model. Int. J. Natural Eng. Sci. 2(1): 57-62.

Pandey, A.N. and N.K. Thakrar, 1997. Effect of chloride salinity on survival and growth ofProsopischilensisseedlings. Trop. Ecol., 38: 145-148.

Rahman, M., S.A. Kayani and S. Gul, 2000. Combined effects of temperature and salinity stress Torech, F.R. and L.M. Thompson, 1993. Soils and soil fertility. Oxford University Press, New York.

\section{Citation for this article}

Mohammed Awad, Samir G. Al Solaimani and Fathy S. El-Nakhlawy, 2014. Effect of Soil Salinity at Germination and Early Growth Stages of two Maize (Zea mays L.) Cultivars in Saudi Arabia. J. Biosci. Agric. Res.01 (01): 47-53. 